\title{
Medievalista
}

Online

$10 \mid 2011$

Número 10

\section{A historiografia da arquitectura da época românica em Portugal (1870-2010).}

Tese de Doutoramento em História da Arte apresentada à Faculdade de Letras da Universidade do Porto, Agosto 2010. Orientação da Professora Doutora Lúcia Maria Cardoso Rosas.

\section{Maria Leonor Botelho}

\section{(2) OpenEdition}

12 Journals

\section{Edição electrónica}

URL: http://journals.openedition.org/medievalista/202

DOI: 10.4000/medievalista.202

ISSN: 1646-740X

\section{Editora}

Instituto de Estudos Medievais - FCSH-UNL

Refêrencia eletrónica

Maria Leonor Botelho, « A historiografia da arquitectura da época românica em Portugal (1870-2010) », Medievalista [Online], 10 | 2011, posto online no dia 01 julho 2011, consultado o 22 setembro 2020. URL : http://journals.openedition.org/medievalista/202 ; DOI : https://doi.org/10.4000/medievalista. 202

\section{(c) (7) (8)}

Mediavalista está licenciado com uma Licença Creative Commons - Atribuição-NãoComercial 4.0 Internacional. 
Título Apresentação de Tese.

A historiografia da arquitectura da época românica em Portugal (1870-2010).

Tese de Doutoramento em História da Arte apresentada à Faculdade de Letras da Universidade do Porto, Agosto 2010. Orientação da Professora Doutora Lúcia Maria Cardoso Rosas.

Autor(es): Maria Leonor Botelho

Enquadramento Institucional: Membro do Instituto de Estudos Medievais, FCSH-UNL; Membro do CEPESE-FLUP

Contacto: leonorbotelho@gmail.com

Fonte: Medievalista [Em linha]. №10, (Julho 2011). Direc. José Mattoso. Lisboa: IEM. Disponível em: http://www2.fcsh.unl.pt/iem/medievalista/

ISSN: 1646-740X 


\section{Apresentação de Tese.}

\section{A historiografia da arquitectura da época românica em Portugal}

(1870-2010).

Tese de Doutoramento em História da Arte apresentada à Faculdade de Letras da Universidade do Porto, Agosto 2010. Orientação da Professora Doutora Lúcia Maria Cardoso Rosas.

\section{Maria Leonor Botelho}

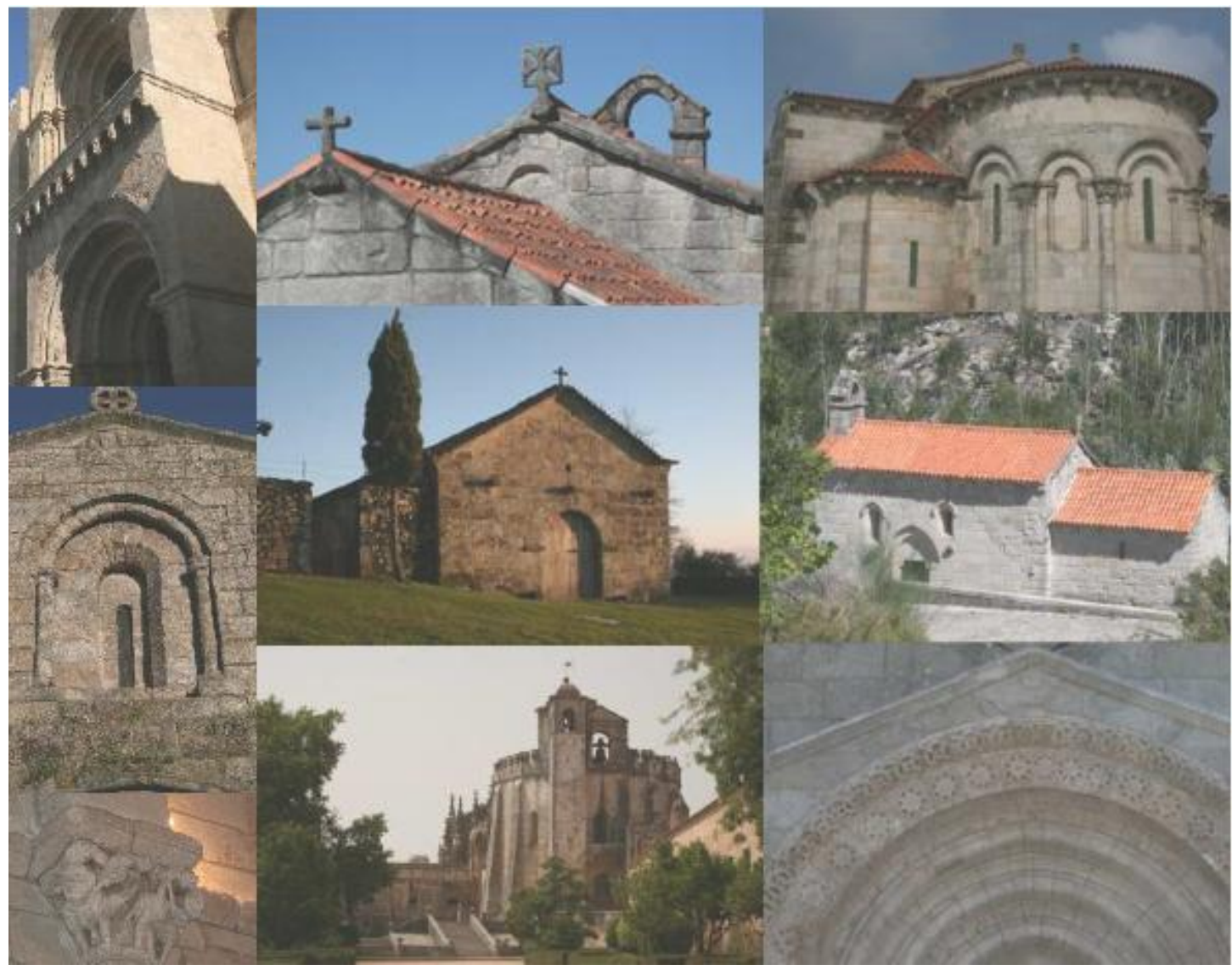

No quadro internacional, foi a partir do século XVII que se começou a valorizar a arquitectura medieval, acentuando-se essa mesma valorização durante o século XIX. Só então, no primeiro quartel de Oitocentos, começam a surgir os primeiros estudos que diferenciam as características formais, construtivas e iconográficas do estilo românico face estilo ao gótico. O estabelecimento de metodologias, a definição de cronologias e a caracterização estilística criaram um quadro

Medievalísta online $\mathrm{N}^{\circ} 10 \mid$ Julho - Dezembro 2011 @ IEM - Instituto de Estudos Medievais 2 www2.fcsh.unl.pt/iem/medievalista 
conceptual e lançaram as bases para o avanço da disciplina no que diz respeito à alteridade do românico relativamente ao gótico.

Em Portugal, o estudo sobre românico surge tardiamente quando comparado com a restante realidade europeia. Datando de 1870 a primeira obra consagrada a este estilo artístico, o seu estudo estendeu-se até aos nossos dias, afirmando-se através de sucessivas fases de conhecimento que reflectem abordagens, temas e problemáticas bem datadas. No entanto, as conquistas e evoluções que a historiografia sobre a matéria foi fazendo, materializada num vasto número de trabalhos editados, contribuíram e muito para o conhecimento actual sobre o românico português. A imagem que se foi construindo do românico acompanha a evolução da escrita sobre este momento tão representativo da arquitectura portuguesa, conotado com a formação de Portugal e com o reinado de D. Afonso Henriques (1143-1185). Esta concepção influiu sobre o modo como se restaurou a arquitectura da época românica sensivelmente ao longo da primeira metade do século XX. E isto é tanto mais significativo quanto daqui decorre a imagem actual da arquitectura românica, tal como a conhecemos hoje.

Ao longo desta ampla cronologia, destacara-se três autores pela ruptura conceptual que o seu pensamento e a sua escrita sobre românico definiram. Deve-se a Augusto Filipe Simões (18351884) a publicação da primeira obra consagrada à arquitectura românica, as Reliquias da architectura romano-byzantina em Portugal e particularmente na cidade de Coimbra, dada ao prelo em 1870. Com Manuel Monteiro (1879-1952) foram lançadas as bases da posterior historiografia sobre a arquitectura da época românica em Portugal, definindo tipologias, classificando dialectos, estabelecendo cronologias e identificando influências. Só mais tarde, com Carlos Alberto Ferreira de Almeida (1934-1996) é que se voltou a sentir uma nova ruptura conceptual na escrita sobre românico, tendo este autor, além de muitos outros aspectos, procurado compreender o românico na sua época e na sua profunda relação antropológica com o território onde se insere.

A originalidade do românico português foi sendo reconhecida pela historiografia da especialidade. A sua íntima relação com o território, a importância nuclear que os seus testemunhos arquitectónicos assumiram na organização territorial, aos mais diversos níveis, foi sendo assimilada por aqueles que se consagram ao seu estudo. Acresce ainda a percepção da forte presença de influências estrangeiras, apesar das problemáticas que se lhe associam, adaptadas que foram num contexto muito específico, onde as pré-existências assumem um papel nuclear, acentuam ainda mais o carácter único da arquitectura portuguesa da época românica. 


\section{The historiography of the Romanesque period architecture in Portugal (1870-2010)}

In the international sphere, the appreciation of the medieval architecture commenced in the 17th century and increased throughout the 19th century. Only at that stage, in the first quarter of the 1800s, do the first studies which differentiate the formal, constructive and iconographic characteristics of the Romanesque style compared to the Gothic style begin to appear. The establishment of methodologies, the definition of chronologies and the stylistic characterization created a conceptual framework and launched the grounds for the development of the discipline in what concerns the alter ego of the Romanesque in relation to the Gothic

In Portugal, the study of the Romanesque occurs rather late when compared to the remaining European reality. The first artwork devoted to this artistic style dates from 1870 and its study has been carried out until the present day, being defined through successive phases of knowledge which reflect well dated approaches, themes and problematics. Nevertheless, the historiography conquests and developments made on the subject in the meantime, which materialize in a vast number of published works, largely contributed to the actual knowledge of the Portuguese Romanesque. The image that was construed of the Romanesque escorts the evolution of writings regarding such a representative moment of Portuguese architecture, which is linked to the foundation of Portugal and the kingdom of D. Afonso Henriques (1143-1185). This understanding influenced the manner in which the Romanesque period architecture was restored roughly during the first half of the $20^{\text {th }}$ century. This is even more significant whereas this results in the current image of the Romanesque architecture, as we know it today.

Throughout this wide chronology, three authors are distinguished due to the conceptual breakout defined by their thoughts and their writings. The publishing of the first artwork devoted to the Romanesque architecture, the Reliquias da architectura romano-byzantina em Portugal e particularmente na cidade de Coimbra, dated 1870 is owed to Augusto Filipe Simões (1835-1884). With Manuel Monteiro (1879-1952) the grounds of the subsequent historiography on Romanesque period architecture in Portugal were launched, by defining typologies, classifying dialects, establishing chronologies and identifying influences. Only later with Carlos Alberto Ferreira de Almeida (1934-1996) a new conceptual breakout in the writings on Romanesque was felt, due to the fact that this author, amongst many other aspects, tried to understand the Romanesque in its era and its profound anthropologic relationship with the territory where it is located. 
The originality of the Portuguese Romanesque commenced being recognized by the Romanesque historiography. Its intimate relationship with the territory, the nuclear importance which its architectonic testimonies acquire in the territorial organization, at diversified levels, has been taken on board by those devoted to its study. Additionally, the perception of the strong presence of foreign influences, despite the associated problematics and adapted in a specific context where prior artistic existences acquired a nuclear role, enhance even more the unique character of the Portuguese architecture in the Romanesque period.

\section{COMO CITAR ESTE ARTIGO}

\section{Referência electrónica:}

BOTELHO, Maria Leonor - A historiografia da arquitectura da época românica em Portugal (1870-2010). Tese de Doutoramento em História da Arte apresentada à Faculdade de Letras da Universidade do Porto 2 Agosto 2010. Orientação da Professora Doutora Lúcia Maria Cardoso Rosas. Medievalista [Em linha]. №10, (Julho de 2011). [Consultado dd.mm.aaaa]. Disponível em http://www2.fcsh.unl.pt/iem/medievalista/MEDIEVALISTA10lbotelho1110.html. ISSN 1646-740X.
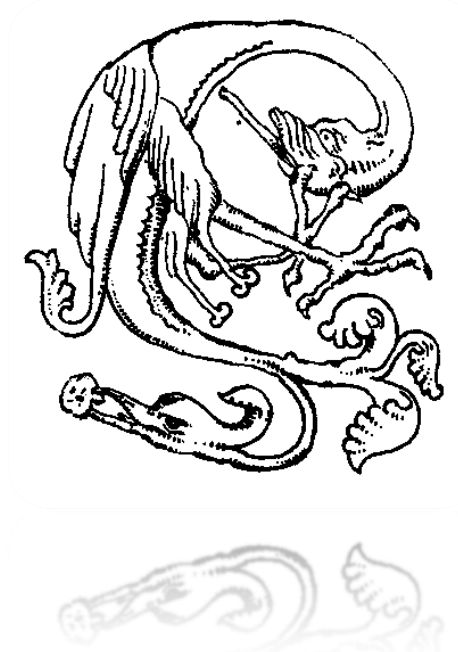